DOI: https://doi.org/10.33739/2587-5434-2020-3-78-84

\title{
PECULIARITIES OF ANALYSIS OF STORIES OF I.S. TURGENEV TAKING INTO ACCOUNT THEIR GENRE IN PECULIARITY SCHOOL STUDIES
}

\author{
Aigul Baituova \\ PhD, Assistant Professor \\ Khoja Akhmet Yassawi International \\ Kazakh-Turkish University \\ (Turkestan, Kazakhstan) \\ e-mail: baituaigul.ru
}

\begin{abstract}
The article is devoted to the study of the influence of analysis features on the study of I. S. Turgenev's stories from the school curriculum. In the course of the work, it was described the established traditions of building literature lessons in accordance with the system of genre and issues of works, as well as a number of questions and tasks for the purpose of updating the cognitive interest of students.

The purpose. To reveal the originality of genre poetics of "Notes of the hunter" I.S. Turgenev and studying this work at school.

Results. Thestudy of Turgenev's work, the immersion of students in his art world, begin in the $5^{\text {th }}$ grade. The school has developed a strong tradition of thematic and genre study of his works: in the $5-6^{\text {th }}$ grades, the stories "Mumu" and "Bezhin Meadow" are studied, in the $8^{\text {th }}$ grade - the story "Asya", in the $10^{\text {th }}$ grade - the novel "Fathers and children" and review one more of the novels. Originality. The introduction of film viewing literature into the structure of the lesson from the point of view of methodological science refers to methods of translating a literary work into works of other arts and can be useful in the process of studying the original text of a story. Using this technique allows you to compare and rethink equally the images of the heroes of the story and the film, as well as the concept of the author's worldview as a whole.
\end{abstract}

Conclusion. Based on our studies, we come to the following conclusions:

1) The content of educational material in secondary and high school contains an established tradition of building lessons in literature in accordance with the system of the genre and problems of works. At the same time, the analysis of Turgenev's stories comes down to focusing on the character parts of the works, while landscape plans are not taken into special consideration. Moreover, the concept of landscape is a unique author's development, the analysis of which is of great practical importance for understanding Turgenev's worldview.

2) Due to the unique structure of stylistic coloring methods, the concept of landscape is conveyed to the reader in a peculiar dynamics, which is characterized by the play of light and shadow, the change of colors, the transmission of sounds.

Keywords: worldview, creativity, actualization, landscape concept, cognitive interest, cycle of stories 


\title{
ОСОБЕННОСТИ АНАЛИЗА РАССКАЗОВ И.С.ТУРГЕНЕВА С УЧЕТОМ ИХ ЖАНРОВОГО СВОЕОБРАЗИЯ В ШКОЛЬНОМ ИЗУЧЕНИИ
}

\author{
Айгуль Назировна Байтуова \\ Кандидат филологических наук, доцент \\ Международный Казахско-турецкий университет \\ им. Ходжи Ахмеда Ясави \\ (Туркестан, Казахстан) \\ e-mail: baituaigul.ru
}

\begin{abstract}
Аннотация. Статья посвящена изучению влияния особенностей анализа на изучение рассказов И. С. Тургенева из школьной программы. В ходе работы описаны сложившиеся традиции построения уроков литературы в соответствии с системой жанровых и проблемных вопросов произведений, а также ряд вопросов и задач с целью актуализации познавательного интереса учащихся.

Цель. Выявить оригинальность жанровой поэтики «Записок охотника» И. С. Тургенева и изучения этой работы в школе.

Результаты. Изучение творчества Тургенева, погружение учеников в его мир искусства, начинается в 5 классе. В школе сложились прочные традиции тематического и жанрового изучения его произведений: в 5-6 классах изучаются повести «Муму» и «Бежин луг», в 8 классе - повесть «Ася», в 10 классе - роман «Отцы и дети» и рецензия еще на один из романов.
\end{abstract}

Оригинальность. Введение кинопросмотра литературы в структуру урока с точки зрения методологической науки относится к методам перевода литературного произведения в произведения других искусств и может быть полезным в процессе изучения оригинального текста рассказа. Использование данной методики позволяет сравнить и переосмыслить в равной степени образы героев сюжета и фильма, а также концепцию мировоззрения автора в целом.

Выводы, сделанные по результатам наших исследований, позволяют сделать следующие выводы:

1) Содержание учебного материала в средней и старшей школе содержит сложившуюся традицию построения уроков литературы в соответствии с системой жанров и проблемами произведений. В то же время анализ рассказов Тургенева сводится к сосредоточению внимания на характерных частях произведений, в то время как ландшафтные планы не принимаются во внимание. Более того, концепция пейзажа - это уникальная авторская разработка, анализ которой имеет большое практическое значение для понимания мировоззрения Тургенева.

2) Благодаря уникальной структуре стилистических приемов раскрашивания, концепция пейзажа передается читателю в своеобразной динамике, которая характеризуется игрой света и тени, сменой цветов, передачей звуков.

Ключевые слова: мировоззрение, творчество, актуализация, концепция пейзажа, познавательный интерес, цикл рассказов

\section{INTRODUCTION}

Having studied I. S. Turgenev's works extensive opportunities have been provided for the formation of students' world outlook, their high-level culture and intelligence. The famous Russian public figure Anatoly Fedorovich Koni in his essay "In Memory of Turgenev" noted: "Turgenev in his creative works reminds me of a Gothic temple, the walls of which are deeply buried in the ground, which tend upward, enchanting the eye with their colored radiant windows, graceful spans and lace carvings and, passing into slender towers, boldly rise into the clear sky, into the sky of sublime aspirations, the nobility of thought and feeling, to the sky of the moral ideal." 
Turgenev's works are based on an unshakable belief in the triumph of good over evil, despite the fact that the fates of Turgenev's characters are often dramatic. M. E. Saltykov-Shchedrin, delighted with the novel "Noble Nest", wrote: "Regarding all Turgenev's works, we can say that after reading them it is easy to breathe, easy to believe, warmth is felt. You clearly feel the rise of your own moral level, in connection with which you mentally bless and love the author" (Chertov 1998: 13). It is these bright feelings that permeate Turgenev's works through and through that arouse genuine interest in the modern reader.

Studying Turgenev's work, who is the successor of the literary traditions of Pushkin and Gogol and also belongs to the adherents of Russian realistic literature, special attention should be paid to moral and aesthetic problems, the author's understanding of human vocation, attitude to people, to the world, since it is these universal human issues that are an actual sphere of secondary school students' interests. Thus, the works selected by modern literature programs for middle grades make it possible to draw the attention of students to moral problems, expand life impressions, contribute to the formation of their artistic taste; therefore, the primary task of a teacher of Russian language and literature is to instill in students' souls a keen interest of Turgenev's creativity.

\section{STATEMENT OF THE PROBLEM}

The actualization of the need of the modern school in organizing a comprehensive, methodically grounded system of lessons dedicated to Turgenev's work prompts us to study his creative work taking into account their genre originality. At the moment, the question of studying Turgenev's story in the aspect of the genre approach has not been resolved, although without mastering the basic, fundamental principles and methods of comprehending the artistic nature of the work, the transition to a course on a historical and literary basis in grades 10-11 is abrupt and unprepared. It is the aspect that determines the research problem, to which this article is devoted.

Purpose. To reveal the originality of the genre poetics of I. S. Turgenev's "Notes of a Hunter" and study this work at school.

\section{RESEARCH METHODS}

In the theory and practice of teaching Russian literature, there are several ways to study the writer's biography considering the age of students. In grades $5-6$, brief biographical information about the writer is given, in grades $7-8$, the life of a writer is described in the genre of a short biographical sketch. In high school, when studying a monographic topic, it is proposed to study a biography in conjunction with creativity, using a historical and literary approach to the consideration of literary phenomena. Despite the fact that these methods of studying the biography of a writer have been tested by long-term school practice, their productivity can only be spoken about if the content component of biographical lessons and teaching materials is successfully developed that correspond to the age-specific psychological characteristics of students. Many teachers suggested that it would be more effective to place information about the main dates of the writer's life in a literature textbook. And, this concerns all writers, not just Turgenev.

\section{SCIENTIFIC NOVELTY OF THE RESEARCH RESULTS}

The study of Turgenev's work, students' immersion in his artistic world begins in the 5th grade. The school has developed a stable tradition of thematic and genre study of his works: in the 5th-6th grades the stories "Mumu" and "Bezhin Meadow" are studied, in the 8th grade - the story "Asya", in the 10th - the novel "Fathers and Children" and one more novels ("Rudin" or "Noble's Nest"). A direct interest for our work is the study of stories. We further propose to study this issue in more detail using the example of the cycle of stories "Notes of a Hunter". Speaking about the genre of this work, it should be noted that the given issue, first of all, continues to attract linguists' attention due to its unique structure and originality. The novelty lies in the fact that the genre of "Notes of a Hunter" is manifested in the transition from an essay in a story. At the same time, the author himself referred to his work as "my essays about the Russian people, the strangest and 
most amazing people that there is in the world" (Turgenev 2016: 32). V. Lebedev's opinion regarding the genre originality of Turgenev's work is expressed as follows: the cycle "Notes of a Hunter" is something more than just a selection of various stories, mechanically collected in a book and outwardly bound by a common title. This is an organic unity, with special internal patterns generated by figurative interaction, the relationship of stories. This relationship creates a poetic context that expands infinitely the artistic capacity of its constituent essays in the book" (Lebedev 2008: 15). Traditionally, at the lessons studying the story "Bezhin Meadow", the main focus was on the description of the images of peasant children and their "terrible" stories. At the same time, the famous landscapes described by Turgenev, which are a concentration of literary art, praised by the author in all nuances, remained outside the field of interest. However, this story first of all opens up to young readers Turgenev's world of nature, presented in the cycle of stories "Notes of a Hunter". The natural world of Turgenev appears before readers in a kind of dynamics: the author's fantasy is not limited to the description of simple pictures of nature, but also harmoniously complements them with such details as the play of light and shadow, color change, sounds and smells of the environment surrounding the characters. Thanks to this artistic method of description, Turgenev's landscapes are filled with vital energy, they give the opportunity being unfolded in time and space. Through such landscapes, the author conveys to the reader the essence of the spiritual life of the heroes with its fluidity and changes, reveals the beauties of the world in moments of being. Some of his landscapes sound like poetry in prose, like a poem about a lyrical hero who discovers and comprehends the natural world and his inner soul. As for Turgenev's story "Notes of a Hunter" the researcher A. P. Valgin states that Turgenev was an outstanding stylist, "whose beauty and elegance of verbal painting was unmatched among his contemporaries" (Valagin 1992: 28.). This statement can be demonstrated to students by referring to the first description of landscape in the story "Bezhinlug": "From the very early morning the sky is clear; the morning dawn does not glow with fire: it spreads with a gentle blush. The sun is not fiery, not red-hot, as during a sultry drought, not dull-purple, as before a storm, but bright and welcomingly radiant - peacefully rises under a narrow and long cloud, shines freshly and plunges into its purple fog. The upper, thin edge of the stretched cloud will sparkle with snakes; their shine is similar to the shine of forged silver ... " (Turgenev 1980: 84).

In Turgenev's description of the morning landscape, there is a predominance of gentle, tender, caressing tones. The beauty of the color scheme of a summer morning is conveyed by the author through the use of such epithets as a gentle blush, a greeting - a radiant sun, purple fog, etc. Thus, the spatial construction of the landscape is conveyed in such a way that the hero, being in the midst of the freshness and purity of morning colors, directs his gaze into the sky, towards the cherished dream. This description of the early morning in the story "Bezhin Meadow" can be compared with the painting by the French artist Jean-BaptisteCamille Corot's "Morning" (1865, State Hermitage). Corot's painting and Turgenev's morning landscape are combined through a similar choice of colors, the described time of day, the image of light and golden rays of the sun cutting through the transparent purple fog. However, if the canvas by Camille Corot depicts early morning, then Turgenev's detailed description of the landscape is a sequence of morning - afternoon evening, and affects the transition from morning dawn to the last reflection of evening sunset.

The important fact is that the period of creation of the cycle of stories "Notes of a Hunter" coincides with the moment of the highest flowering of the writer's abilities to create a skillful landscape in literature. It has been reflected in this cycle of works demonstrating his unique vision of nature in paints, light, colors, tones and shades. At the same time, it should be noted that here for the first time in Russian literature the landscape is depicted in a realistic manner, excluding a variety of romantic exoticism. The influence of the Barbizon artists is traced here, whose works are characterized by the realistic depiction of natural objects in the vicinity of the village of Barbizon. In this regard, at the lessons devoted to the study of the cycle of stories "Notes of a Hunter", it has been allowed to use photographs of paintings by Barbizon artists as a visual aid in identifying the intermediate essence of the writer's skill.

The manifestation of realism in Turgenev's work may also be due to the influence of the "natural school", the creator of which was V.G. Belinsky, who called on writers to portray the working peasantry in 
the form of a peasant - whose life circumstances lead to an endless series of suffering. At the same time, such a character does not lose the ability to preserve human dignity, his mind is bright, and his heart is filled with virtuous thoughts. These circumstances, according to Belinsky, should encourage writers to express their opinions about the common people with love and compassion. Turgenev's original response to this call is the creation of the author's landscape concept, the task of which is to try to comprehend the deepest secrets of the human soul, his character, thoughts that are revealed in interaction with nature. So the living environment of the Russian people, their attitude to the nature of their native places, according to Turgenev, helps to reveal to the reader the essence of the national character. In this regard, it seems not accidental that the cycle "Notes of a Hunter" ends with the story "Forest and Steppe", in which nature acts as a symbolic space characterizing the features of the Russian national character. The epigraph to this story, which is a kind of appeal to the reader, is the lyrical depiction of the feelings that embrace the author. As the author himself, the connection with nature is one of the most important parts of life. One way or another, in almost every story of the cycle, Turgenev connects his own perception of the world with the surrounding world of the hero.

In Turgenev's stories, the landscape, among other functions, acts as a threshold when a new character appears in the course of the narrative. Thus, the landscape acts as the main background against which the outline of the character appears. For example, Akulina from the story "Appointment" relates to the image of a grove "trembling after the rain", a thunderstorm becomes the background for Biryuk ("Biryuk") appearing before the readers, the boys' scary stories are preceded by a description of Bezhin's meadow at night, etc.

All the most important events forming the basis of the plot in the cycle of stories "Notes of a Hunter" take place against the background of nature. All serious events in "Notes of a Hunter", which form the basis of the plot, take place against the background of nature. Turgenev portrays peasants either to a greater or lesser degree with nature, or in the context of a total rejection of the environment. At the same time, the level of human morality directly depends on his connection with nature. In this interpretation of the plot, a person who rejects connection with nature is the owner of negative character traits. So, in the cycle "Notes of a Hunter" the author created two types of heroes, acting in opposition. These include the "savage lordship", whose unjustified cruelty is mercilessly denounced and debunked by the author, and the peasantry living in unity with nature, under the guise of which Turgenev sees the features of a national Russian character, oppressed but unbroken. Thus, in Turgenev's stories, nature is a certain criterion in assessing the moral and ethical qualities of the heroes, and therefore the study of the role of the landscape at literature lessons dedicated to Turgenev's work in the middle level of the school is of particular importance for the formation of students' ideas about the writer's worldview.

In order to activate the cognitive activity of schoolchildren in the process of their study of the cycle of stories "Notes of a Hunter", the following system of questions and tasks can be proposed:

1. Having found descriptions of nature at different times of the day in Turgenev's story, learn expressive reading. Use your own drawings to depict your idea of one or more of these landscapes.

2. Based on Turgenev's landscapes, try to trace the changes occurring in nature during the day (changes in light, shadows, colors, descriptions of the sky, elements of vegetation).

3. Explain your impressions while reading the descriptions of Turgenev's landscapes. Does your mood change describing pictures of nature?

4. Examine the photograph of Camille Corot's "Morning". What are its similarities and differences with the description of the morning landscape of Turgenev? What similarities and differences do you find with the description of Turgenev's morning landscape?

\section{THE MAIN RESULTS OF THE RESEARCH}

In addition concerning the aesthetic plan of nature perception considered by us above, Turgenev's stories capture such a moment, no less interesting for senior students, such as the philosophical aspect of the imagery of nature. The original author's concept of the landscape, created by the Russian writer, has been 
complemented by Schopenhauer's idea, a representative of the existential philosophical trend. The meaning of this idea comes down to perceiving nature as a blind force, acting according to general laws and characterized by the absence of individuality. Such nature acts in the same way in all its millions of manifestations. In the perception of Turgenev, a person deprived of a spiritual connection with nature is unable to come to terms with its indifference in relation to the transience of human existence. While a natural person does not experience such fear in the face of death ... Quite eloquently, this concept is embodied in Turgenev's story "Death" when describing the death of a simple peasant: "A Russian peasant is dying amazingly! His state before his death cannot be called indifference or stupidity; he dies as if he is performing a ceremony: cold and simple" (Turgenev 1998: 200).

Today, the film adaptations of Turgenev's stories from the cycle "Notes of a Hunter" as "Biryuk", "Bezhin Meadow", "Life and Death of the Nobleman Chertopkhanov" have been created. The introduction of watching films into the structure of the literature lesson from the viewpoint of methodological science refers to the methods of translating a literary work. The works of other arts can be useful in the process of studying the original text of the story. The use of such a technique allows one to compare and rethink in equal measure both the images of the heroes of the story and the film, and the concept of the author's worldview in general. It is appropriate to attach the following list of tasks to this type of educational activity:

1) Compare certain episodes from the film with the original text of the story in order to compare them and then determine the author's interpretation of the plot in different types of art.

2) Describe the system of characters in the film and story according to the plan (appearance, speech, actions, etc.)

3) Writing reviews of a story and a movie to train students' creative abilities.

\section{CONCLUSIONS AND SPECIFIC PROPOSALS OF THE AUTHOR}

Based on the carried out research, we come to the following conclusions:

1) The content of educational material in middle and high school contains established traditions of constructing literature lessons in accordance with the system of genre and problematics of works. At the same time, the analysis of Turgenev's stories comes down to focusing on the character parts of the works, while landscape plans are not taken into account. At the same time, the concept of the landscape is a unique author's development, the analysis of which is of great practical importance for understanding Turgenev's worldview.

2) Due to the unique structure of methods of stylistic coloring, the concept of the landscape is transmitted to the reader in a kind of dynamics, which is characterized by the play of light and shadow, changing colors, and the transmission of sounds.

3) The author uses the concept of landscapes not only to describe the beauty of nature, but also to reveal the essence of the national character of the Russian people. At the same time, nature acts as a kind of measure of the moral and ethical image of society. This aspect also determines the formation of a system of characters, consisting of two lines: "wild lordship", rejecting the connection with nature and, in this regard, has a set of negative character traits, and the peasantry, living in harmony with nature, in accordance with which they have higher moral qualities. Also, against the background of nature, all more or less significant events in the life of the characters take place.

4) With the aim of a deeper study of Turgenev's stories in literature lessons, it is relevant to use such forms of art as painting and cinema. For this purpose, during the study, a number of special tasks for students have been developed. 
Thus, a deeper, in comparison with the traditional analysis of Turgenev's stories from the series "Notes of a Hunter" provides students with a vast field for the development of cognitive interests not only in literature, but also in philosophy, painting and cinematography.

\section{LIST OF REFERENCES}

Valagin, A.P. (1992). «I.S. Turgenev «Notes of a Hunter». The experience of analyzing reading // Literature at school. 1992. No. 3., p.p. 26-30.

Chertov, V.F. (1998). Problems of theory and practice of modern literary education: Materials of the seminar for young teachers and graduate students. Issue 2 / Comp. V.F. Chertov. M.: Culture, p. 33.

Koni, A.F. (1980). Memories of writers. M .: Foliant, p. 656.

Lebedev, Yu.V. (2008). Russia and Russians in the novel by I.S. Turgenev «Noble nest» / Yu.V. Lebedev. // Literature at school. No. 10. p. p. 14-20.

Turgenev, I.S. (2016). Literary and everyday memories. M .: Education, p. 210.

Turgenev, I.S. (1980). Complete collection of works and letters: in 30 volumes. Moscow: publishing house «Nauka», V. 4., p. 687.

\section{For citation:}

Baituova, A. (2020) Peculiarities of analysis of stories of I.S. Turgenev taking into account their genre in peculiarity school studies // International Scientific-Pedagogical Organization of Philologists

“WEST-EAST"(ISPOP). Scientific Journal WEST-EAST. Vol 3 N2 (October, 2020). pp. 78-84.

https://doi.org/10.33739/2587-5434-2020-3-78-84

\section{Для цитирования:}

Байтуова, А. Н. (2020) Особенности анализа рассказов И. С. Тургенева с учетом их жанра в специфике школьного образования // International Scientific-Pedagogical Organization of Philologists “ WEST-EAST ” (ISPOP). Scientific Journal WEST-EAST. Vol 3 N2 (October, 2020). C. 78-84. https://doi.org/10.33739/2587-5434-2020-3-78-84

\section{Information about the author:}

Baituova Aigul - PhD, Assistant Professor of the Department of World Languages of Khoja Akhmet Yassawi International Kazakh-Turkish University (Turkestan, Kazakhstan). ORCID 0000-0002-4928-0280 e-mail: baituaigul.ru

Байтуова Айгуль Назировна - кандидат филологических наук, доцент, Международный Казахскотурецкий университет им. Ходжа Ахмет Яссави (Туркестан, Казахстан)

электронная почта: baituaigul.ru

Manuscript received: $13 / 08 / 2020$

Accepted for publication: $16 / 09 / 2020$

Рукопись получена: 13/08/2019

Принята к печати: 16/09/2020

\section{International Scientific-Pedagogical Organization of Philologists "West-East" - ISPOP SCIENTIFIC JOURNAL "WEST-EAST" \\ ISSN (print) - 2587-5434 ISSN (online) - 2587-5523}

